\title{
Enterococcus haemoperoxidus sp. nov. and Enterococcus moraviensis sp. nov., isolated from water
}

\footnotetext{
1 Czech Collection of Microorganisms, Faculty of Science, Masaryk University, Tvrdého 14, 60200 Brno, Czech Republic

2 Laboratory of Bacteriology, Faculty of Veterinary Medicine Ghent University, Salisburylaan 133 , B-9820 Ghent, Belgium

3 BCCM/LMG Bacteria Collection, Ghent University, K. L. Ledeganckstraat 35 B-9000 Ghent, Belgium

4 Department of Genetics and Molecular Biology, Faculty of Science, Masaryk University, Kotlářská 2, 61137 Brno, Czech Republic
}

\author{
Pavel Švec, ${ }^{1}$ Luc A. Devriese, ${ }^{2}$ Ivo Sedláček, ${ }^{1}$ Margo Baele, ${ }^{2}$ \\ Marc Vancanneyt, ${ }^{3}$ Freddy Haesebrouck, ${ }^{2}$ Jean Swings ${ }^{3}$ and Jiří Doškař ${ }^{4}$
}

Author for correspondence: Pavel Švec. Tel: +420 5432472 31. Fax: +420 543247339. e-mail:mpavel@sci.muni.cz

\begin{abstract}
A polyphasic taxonomic approach was used to study atypical enterococci isolated from surface waters. All strains were characterized by physiological and biochemical tests as well as by genotyping. The results of biochemical tests and tRNA intergenic length polymorphism analysis (tDNA-PCR) divided all studied strains uniformly into two groups. Because these groups were clearly separated from all enterococcal species described to date, 16S rDNA sequence analysis, DNA base composition analysis and DNA-DNA hybridization of representative strains were done to elucidate the taxonomic position of the analysed groups. On the basis of the results obtained, the names Enterococcus haemoperoxidus (type strain CCM 4851 ${ }^{\top}=$ LMG 19487') and Enterococcus moraviensis (type strain CCM 4856 ${ }^{\top}$ = LMG 19486 ${ }^{\top}$ ) are proposed for the two hitherto undescribed species. The type strains and reference cultures have been deposited in the Czech Collection of Microorganisms (CCM), Masaryk University, Brno, Czech Republic, and in the BCCM/LMG Culture Collection, Ghent University, Belgium.
\end{abstract}

Keywords: Enterococcus haemoperoxidus sp. nov., Enterococcus moraviensis sp. nov., taxonomy, identification, water

\section{INTRODUCTION}

Enterococci are Gram-positive cocci that are commonly isolated from human clinical specimens, some kinds of food and the environment. Recent interest in this bacterial genus has been encouraged by their increasing clinical significance and acquired antibiotic resistance (Facklam et al., 1999; Jett et al., 1994). Therefore, most investigations relate to strains and species isolated from clinical samples. Unfortunately, little exact taxonomic information is available about the strains and species of enterococci occurring in the environment. Enterococci can be isolated from soil, plants, insects and wild animals as well as from water samples. Enterococcus faecalis, Enterococcus faecium, Enterococcus mundtii and Enterococcus casseliflavus are found associated with plants (Devriese et al., 1992). Soil is probably not the natural habitat of enterococci,

The GenBank accession numbers for the 16S rRNA gene sequences of $E$. moraviensis CCM $4856^{\top}$ and $E$. haemoperoxidus CCM $4851^{\top}$ are AF286831 and AF286832, respectively. and their presence therein represents contamination from animals and plants (Deibel, 1964). The incidence of enterococci in waters is generally considered to be due to faecal contamination and these bacteria are monitored during microbiological quality testing of water. In particular, E. faecalis, E. faecium, Enterococcus durans and Enterococcus hirae are considered to be of faecal origin (Godfree et al., 1997). However, enterococci of non-faecal origin may be also found in surface waters. Niemi et al. (1993) described $E$. casseliflavus as a typical species in forest industry wastewaters in Finland, and they isolated atypical enterococcal strains from pristine waters.

A series of atypical enterococci were isolated during an investigation into the occurrence of different enterococcal species in surface waters (Švec \& Sedláček, 1999). All strains were characterized using morphological, physiological as well as biochemical tests, but their phenotypic characteristics did not correspond to those of known enterococcal species. Because of their unclear taxonomic position, analysis of tRNA intergenic length polymorphism (tDNA-PCR), 16S rDNA 
sequencing, DNA base composition analysis and DNA-DNA hybridization were carried out. Our results showed that the enterococcal strains analysed represent two new species, for which the names Enterococcus haemoperoxidus sp. nov. and Enterococcus moraviensis sp. nov. are proposed.

\section{METHODS}

Bacterial strains. The strains analysed in this work were isolated from surface waters by membrane filtration and subsequent incubation of the filters on Slanetz-Bartley agar plates at the $37^{\circ} \mathrm{C}$ during a routine analysis of water quality, as described previously (Svec \& Sedláček, 1999). All strains were isolated from different sampling sites in the region of North Moravia in the Czech Republic (see Table 1).

Phenotypic studies. Isolated strains were cultivated on Columbia agar with $5 \%$ sheep blood. Consequently, growth was checked and characterized on Slanetz-Bartley agar, kanamycin/aesculin/azide agar, BBL Enterococcosel agar, Edwards agar, aesculin/bile agar and skim milk medium. Growth in a $5 \% \quad \mathrm{CO}_{2}$ atmosphere and in a normal atmosphere was compared on blood agar at $37^{\circ} \mathrm{C}$. Tests for growth at various temperatures as well as in $6.5 \% \mathrm{NaCl}$ were performed in brain/heart infusion (BHI) broth and bacteria were cultivated for up to $5 \mathrm{~d}$. Catalase tests were done by dispersing growth from Columbia agar with and without blood in $3 \%$ hydrogen peroxide. Motility was tested on semi-solid medium according to Facklam \& Wilkinson (1981). Group D antigen was tested using a Streptococcal grouping kit (Oxoid). Amylase production was looked for on Columbia agar base containing $0 \cdot 1 \%$ starch. Biochemical tests were performed using API galleries 20 STREP and 50 $\mathrm{CH}$ (bioMérieux) as well as the CRYSTAL Gram-positive ID kit (Becton Dickinson) according to the manufacturers' instructions.

DNA isolation. One loop of a bacterial culture grown overnight on Columbia agar with $5 \%$ sheep blood was suspended in $20 \mu$ lysis buffer $(0.25 \%$ SDS, 0.05 M NaOH) and heated at $95^{\circ} \mathrm{C}$ for $5 \mathrm{~min}$. Subsequently, $180 \mu \mathrm{l}$ sterile distilled water was added and the suspension was centrifuged at 13000 r.p.m. for $5 \mathrm{~min}$. The supernatant was used directly for tDNA-PCR as well as for $16 \mathrm{~S}$ rDNA sequencing.

tRNA intergenic length polymorphism analysis (tDNA-PCR). tDNA-PCR was done using the consensus primers T5A (5'-AGTCCGGTGCTCTAACCAACTGAG-3') and fluorescent-labelled T3B (5'-AGGTCGCGGGTTCGAATCC-3') described by Welsh \& McClelland (1992). Capillary electrophoresis of PCR products was done on an ABI PRISM 310 Genetic Analyzer (Applied Biosystems) as described previously (Baele et al., 2000). Cluster analysis of tDNA-PCR fingerprints was done using the UPGMA algorithm with the PHYLIP software (Felsenstein, 1989) and the dendrogram was visualized using the TREEVIEW program described by Page (1996).

16S rRNA sequence analysis. The $16 \mathrm{~S}$ rRNA gene was amplified using the primers $\alpha \beta$-NOT (5'-TCAAACTAGGACCGAGTC-3') and $\omega_{\mathrm{MB}}\left(5^{\prime}\right.$-TACCTTGTTACTTCACCCCA-3') and the Taq Mastermix (Qiagen). The subsequent sequencing reactions were done using the BigDye Terminator sequencing kit (Applied Biosystems) and forward sequencing primers $*$ Gamma, $* \mathrm{PD}, * \mathrm{O}, * 3, * \mathrm{R}$ and reverse primers Gamma, PD and 3 described by Coenye et al. (1999). The sequences were determined on an ABI PRISM 310 Genetic Analyzer (Applied Biosystems). Cluster analysis was done using program GENEBASE (Applied Maths). Pairwise alignment homologies were calculated and a dendrogram was constructed using the neighbour-joining method with $100 \%$ open gap penalty and $0 \%$ unit gap penalty values.

DNA base composition. DNA was prepared as described elsewhere (Vancanneyt et al., 2001). The enzymic degradation of DNA into nucleosides was done as described by Mesbah et al. (1989). The nucleotide mixture was then separated by HPLC using a Waters SymmetryShield C8

Table 1. Source and locality of isolation of the strains

\begin{tabular}{|ll|}
\hline Strain & \multicolumn{1}{|c|}{ Source and locality } \\
\hline $\begin{array}{l}\text { Enterococcus haemoperoxidus sp. nov. } \\
25(=\mathrm{CCM} 4855)\end{array}$ & River Olše, Třinec \\
$60(=\mathrm{CCM} 4853), 152,313$, & Drinking water, Frýdek-Místek \\
$504(=\mathrm{CCM} 4886), 616$ & \\
382 & Drinking water, Čeladná \\
434 & Spring Hájek, Frýdek-Místek \\
$435,457,473$ & Drinking water, Třinec \\
$440^{\mathrm{T}}\left(=\mathrm{CCM} 4851^{\mathrm{T}}=\mathrm{LMG} 19487^{\mathrm{T}}\right)$ & Service water, Paskov \\
$450(=\mathrm{CCM} 4854)$ & Swimming pool, Frýdek-Místek \\
466 & Swimming pool, Tŕinec \\
$501(=\mathrm{CCM} 4852)$ & Drinking water, Vítkovice \\
562 & Drinking water, Lhotka \\
Enterococcus moraviensis sp. nov. & \\
$206(=\mathrm{CCM} 4857)$ & Drinking water, Čeladná \\
$330^{\mathrm{T}}\left(=\mathrm{CCM} 4856^{\mathrm{T}}=\mathrm{LMG} 19486^{\mathrm{T}}\right)$ & Spring Hájek, Frýdek-Místek \\
$430(=\mathrm{CCM} 4859), 494,568(=\mathrm{CCM} 4885)$, & Drinking water, Frýdek-Místek \\
$570(=\mathrm{CCM} 4858)$ & \\
$531(=\mathrm{CCM} 4860)$ & Drinking water, Fryčovice \\
\hline
\end{tabular}




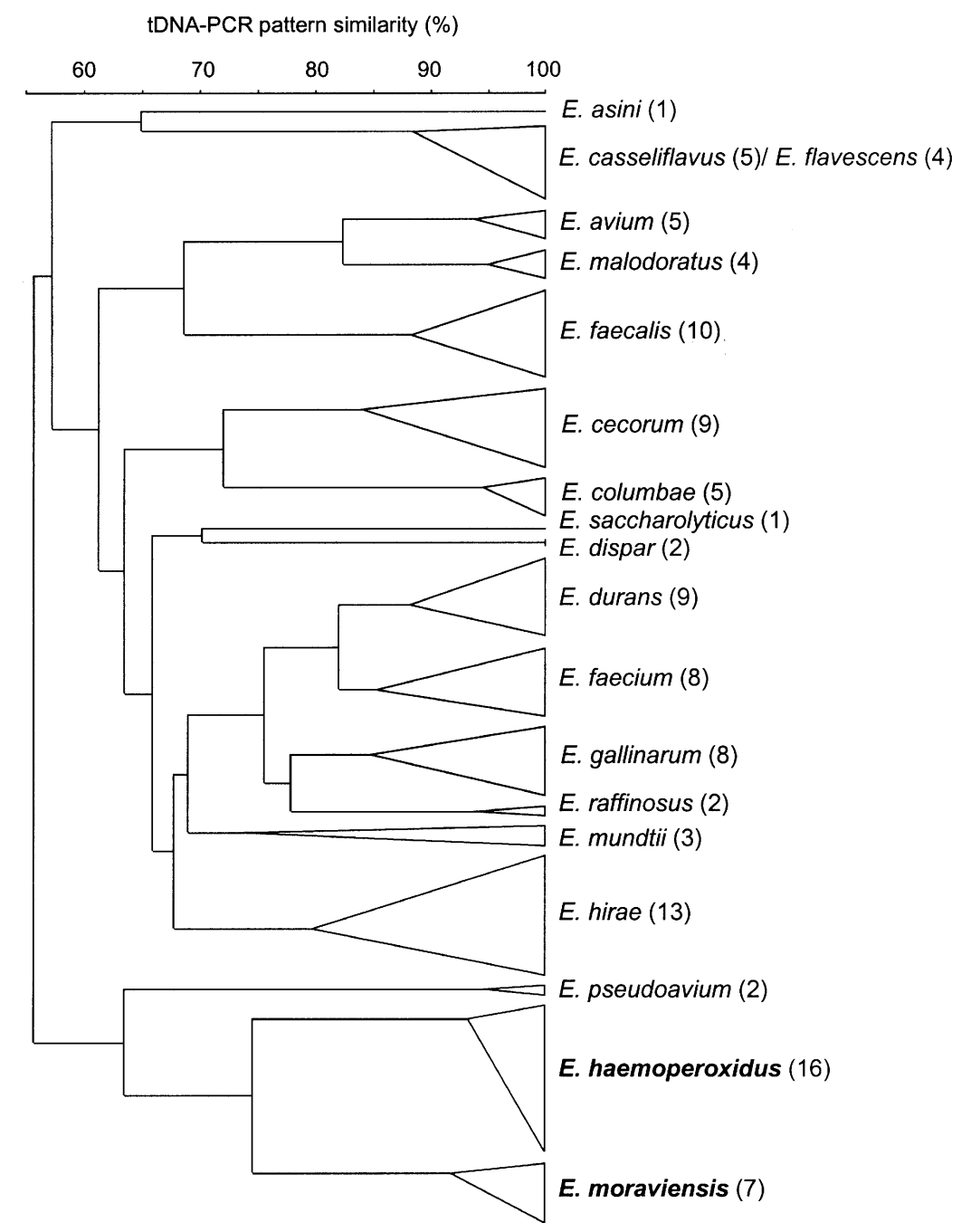

Fig. 1. Dendrogram based on tDNA-PCR fingerprint patterns demonstrating the relatedness between $E$. haemoperoxidus sp. nov., E. moraviensis sp. nov. and other enterococcal species. Numbers of strains analysed are indicated in parentheses.

column thermostatted at $37^{\circ} \mathrm{C}$. The solvent was $0.02 \mathrm{M}$ $\mathrm{NH}_{4} \mathrm{H}_{2} \mathrm{PO}_{4}$ (pH 4.0) with $1.5 \%$ acetonitrile. Non-methylated lambda phage DNA (Sigma) was used as the calibration reference.

DNA-DNA hybridization. Whole genomic DNA of representative strains isolated according to Vancanneyt et al. (2001) was hybridized in microdilution wells with photobiotinlabelled probe DNAs as described by Ezaki et al. (1989). The enzymic reaction intensity was measured using HTS7000 Bio Assay Reader (Perkin Elmer). The hybridization temperature was $32{ }^{\circ} \mathrm{C}$. The hybridization temperature was calculated from the $\mathrm{G}+\mathrm{C}$ content with the formula of De Ley (1970) and corrected for the presence of $50 \%$ formamide in the hybridization mixture (McConaughy et al., 1969).

\section{RESULTS AND DISCUSSION}

\section{Genotypic studies}

tDNA-PCR separated all strains investigated into two unique clusters and showed genetic homogeneity of the strains within each group (Fig. 1). Moreover, the tDNA-PCR fingerprint patterns clearly separated both groups from all enterococcal species included in the database of Department of Bacteriology, Faculty of Veterinary Medicine, University of Ghent, Belgium, described by Baele et al. (2000). Typical tDNA spacer fragment lengths were $74 \cdot 7,257$ and 331.3 bp for the first group (E. haemoperoxidus sp. nov.) and 74, 258 and $332 \cdot 2 \mathrm{bp}$ for the second group (E. moraviensis sp. nov.). Although there were only small differences in the fragment lengths between these two groups, Baele et al. (2000) have shown that some enterococcal species can be differentiated by only 1 bp (E. faecium-E. durans) or 2 bp (Enterococcus avium-Enterococcus malodoratus) differences in length.

This molecular method has been used successfully for species typing of streptococci (De Gheldre et al., 1999; McClelland et al., 1992), acinetobacters (Ehrenstein et al., 1996), staphylococci (Maes et al., 1997; Welsh \& McClelland, 1992) and listerias (Vaneechoutte et al., 1998) and it appears to be reliable for the rapid identification of enterococci as well as for the detection and study of new enterococcal species.

The 16S rRNA sequences of representative strains from each group were determined and compared 


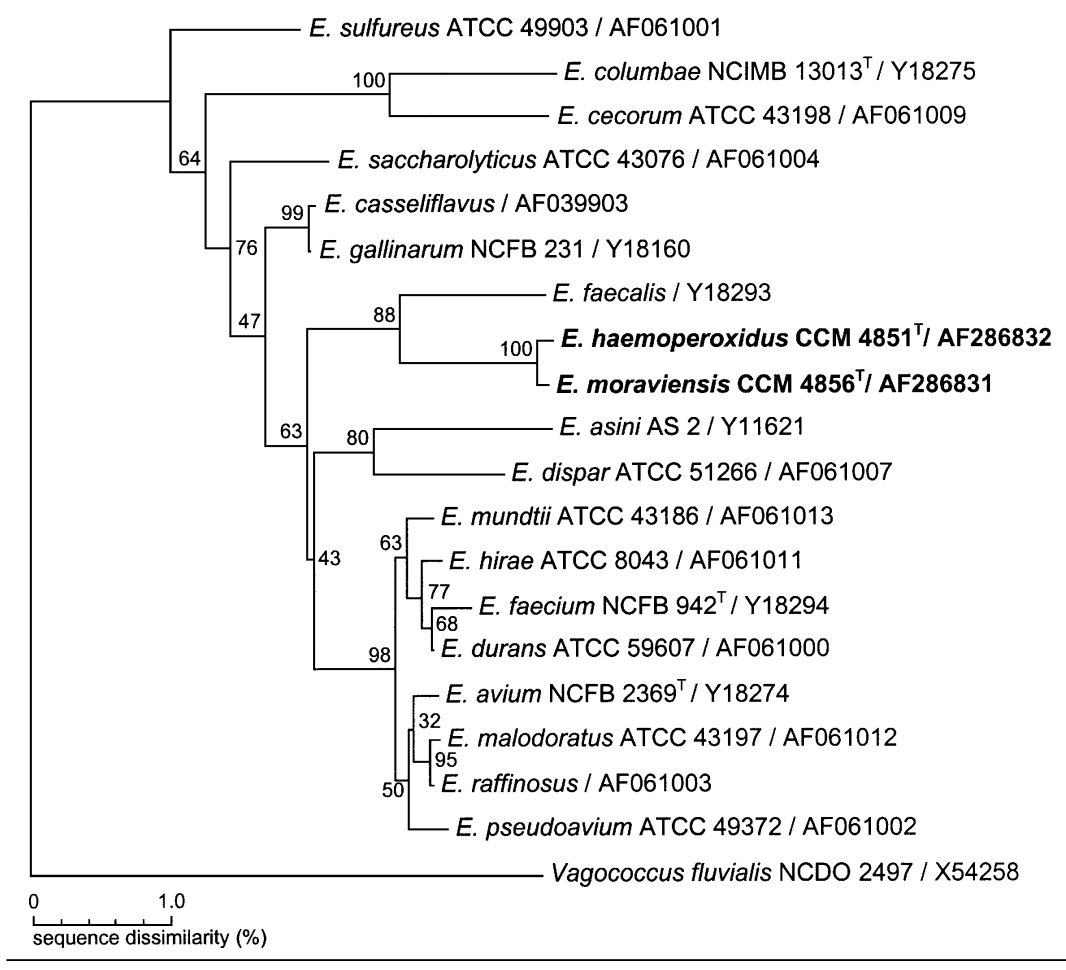

Fig. 2. Distance matrix tree based on $16 \mathrm{~S}$ rRNA gene sequence comparisons showing the phylogenetic relationships of $E$. haemoperoxidus sp. nov., E. moraviensis sp. nov. and all generally recognized Enterococcus species described to date. Vagococcus fluvialis (X54258) was used as the outgroup. Bootstrap percentages are indicated at the branching points of the dendrogram.

Table 2. DNA-DNA homology values of $E$. haemoperoxidus sp. nov., E. moraviensis sp. nov. and the phylogenetically closest species, E. faecalis

\begin{tabular}{|c|c|c|c|c|c|c|}
\hline \multirow[t]{2}{*}{ Strain } & \multirow{2}{*}{$\begin{array}{c}G+C \text { content } \\
(\mathrm{mol} \%)\end{array}$} & \multicolumn{5}{|c|}{ DNA relatedness $(\%)$ : } \\
\hline & & 1 & 2 & 3 & 4 & 5 \\
\hline 1. E. haemoperoxidus CCM $4851^{\mathrm{T}}$ & $35 \cdot 3$ & 100 & & & & \\
\hline 2. E. haemoperoxidus CCM 4886 & $35 \cdot 5$ & 98 & 100 & & & \\
\hline 3. E. moraviensis CCM $4856^{\mathrm{T}}$ & $36 \cdot 3$ & 48 & 43 & 100 & & \\
\hline 4. E. moraviensis CCM 4885 & $35 \cdot 6$ & 46 & 37 & 91 & 100 & \\
\hline 5. E. faecalis $\mathrm{LMG} 7937^{\mathrm{T}}$ & $37 \cdot 7$ & 17 & 19 & 16 & 16 & 100 \\
\hline
\end{tabular}

(Fig. 2). The data showed that these two groups are highly related: $99 \cdot 7 \% 16 \mathrm{~S}$ rRNA sequence similarity was found between strain $330^{\mathrm{T}}$, representative of the one group, and strain $440^{\mathrm{T}}$, representing the other group. The phylogenetically closest species is $E$. faecalis. The $16 \mathrm{~S}$ rDNA sequence similarity of $E$. faecalis NCIMB $775^{\mathrm{T}}$ to strains $330^{\mathrm{T}}$ and $440^{\mathrm{T}}$ was $97 \cdot 4 \%$. The interspecies $16 \mathrm{~S}$ rRNA homologies between enterococcal species are mostly high and exceed the generally accepted value of $97 \%$ for species differentiation. They may be as high as $99.8 \%$, as is the case with E. casseliflavus-Enterococcus gallinarum, or $99 \cdot 7 \%$, for $E$. durans-E. faecium (Williams et al., 1991). However, the percentages of DNA-DNA hybridization of these species are low and clearly indicate their species identity.

Similarly, the DNA-DNA hybridization results (Table 2) obtained with two strains selected from each of the groups studied here and the type strain of the phylogenetically closest species E. faecalis confirmed the species identity of the analysed enterococcal groups, as revealed by tDNA-PCR and 16S rRNA sequencing. These DNA-DNA homology values clearly differentiated the strains from E. faecalis $\mathrm{LMG}$ $7937^{\mathrm{T}}$ and revealed high similarities of the two strains selected from each group (values higher than $90 \%$ ). Moreover, the DNA-DNA homology values between strains of these two groups (37-48\%) confirmed the phylogenetic similarity of these species shown by $16 \mathrm{~S}$ rRNA gene analysis.

On the basis of these results, we propose to add two new species, Enterococcus haemoperoxidus sp. nov. and Enterococcus moraviensis sp. nov., to the genus Enterococcus.

\section{Phenotype studies}

All strains grew well on Columbia agar supplemented with $5 \%$ sheep blood at $37^{\circ} \mathrm{C}$ under aerobic as well as anaerobic conditions. They formed circular and 
smooth colonies with entire margins. Colonies reached about $1 \mathrm{~mm}$ in diameter after $24 \mathrm{~h}$ of cultivation and their growth continued at room temperature up to 3-4 $\mathrm{mm}$. No haemolysis was observed on sheep-blood agar. Growth was enhanced slightly by cultivation in a $5 \% \mathrm{CO}_{2}$ atmosphere and was more abundant at $37^{\circ} \mathrm{C}$ in comparison with 30 or $25^{\circ} \mathrm{C}$. Growth occurred at $10{ }^{\circ} \mathrm{C}$ but was strongly inhibited at $42^{\circ} \mathrm{C}$. Uniform turbidity was produced in BHI broth culture at $37^{\circ} \mathrm{C}$ and all strains were able to grow when the $\mathrm{NaCl}$ content was increased to $6.5 \%$. No change of skim milk medium was detected.

All strains grew on kanamycin/aesculin/azide agar, BBL Enterococcosel agar, Edwards agar and aesculin/ bile agar and were aesculin-positive on all these media. Colonies formed on Slanetz-Bartley agar were small and dark-red with a metallic sheen. They were very similar to colonies of E. faecalis, but smaller.

In complete agreement with the genotypic examinations described above, the biochemical test results divided all strains into two groups and separated them clearly from all described enterococcal species. Although the new species are phylogenetically as well as phenotypically close to E. faecalis, they can be differentiated using a few biochemical tests. Both new species are sorbitol-negative and methyl $\alpha$-Dglucoside-positive, while $E$. faecalis generally gives opposite results for these two tests. Moreover, E. haemoperoxidus is not able to acidify D-tagatose and E. moraviensis is L-arabinose-positive and arginine dihydrolase-negative. Surprisingly, 16 strains (all strains of the proposed E. haemoperoxidus sp. nov.) were clearly and strongly positive in the catalase test when cultivated on blood medium but negative when grown on blood-free medium. Lactic acid bacteria (including enterococci) are generally unable to synthesize haem groups (Gibson et al., 2000; Whittenbury, 1978; Deibel \& Evans, 1960; Smith, 1954). The destruction of peroxide by some enterococcal strains was detected when cultivated on bloodcontaining medium under aerobic conditions. Seeley \& VanDemark (1951) described the formation of peroxidase in Streptococcus faecalis (now E. faecalis) B33 A. The enzyme was formed adaptively (after anaerobic growth, when exposed to air) and differed from classical peroxidase in that it lacked haemin. Deibel (1964) did not detect iron-porphyrin compounds either chemically or spectrophotometrically in catalase-positive $S$. faecalis. Although $S$. faecalis lacks cytochrome pigments, it is able to respire and flavin co-enzymes occupy a central role in aerobic hydrogen transport (Deibel, 1964). Smith (1954) detected flavoprotein compounds, rather than cytochromes, in $S$. faecalis. Finally, Miller et al. (1990) described the flavincontaining NADH peroxidases of $S$. faecalis ATCC 9790 and found greater diversity of these enzymes among the group D streptococci. Although catalase or pseudocatalase production has been described previously in many streptococcus- and enterococcus-like strains (Rurangirwa et al., 2000; Murray, 1990;
Whittenbury, 1978; Deibel, 1964), this is probably the first case of a clearly positive catalase reaction detected in a homogeneous group of enterococcal strains. This simple test could be useful for the differentiation of $E$. haemoperoxidus from other enterococcal species. However, of course, it will be necessary to test more isolates in order to evaluate the catalase test as an identification test for this species.

The two new species can be clearly differentiated from each other by testing for acidification of D-tagatose and $\mathrm{L}$-arabinose as well as by the arginine dihydrolase reaction. The tests most useful for the identification and differentiation of the proposed new species from all enterococci and enterococcal species groups are listed in Table 3.

\section{Description of Enterococcus haemoperoxidus sp. nov.}

Enterococcus haemoperoxidus (hae.mo.per.o'xi.dus. G. n. haema blood; per G. prefix intensification; oxys G. adj. sour; N. L. adj. haemoperoxidus blood peroxide, derived from the ability of the species to decompose hydrogen peroxide into oxygen and water when cultivated on blood-agar media).

Cells are Gram-positive, ovoid cocci, occurring in pairs, short chains or small groups. They are elongated in the direction of the chains. Non-motile. A slightly yellowish pigment may be produced; this pigment is most readily visible when growth is collected from plates within inoculation loops. A positive catalase reaction is clearly evident when cultivated on blood agar, but cells grown on blood-free medium are catalase-negative. Weakly positive in the amylase test. Streptococcal group D antigen-positive. Growth characteristics and physiological traits are as described above. Acid is produced from glycerol, ribose, galactose, D-glucose, D-fructose, D-mannose, methyl $\alpha$-Dglucoside, $N$-acetylglucosamine, amygdalin, arbutin, salicin, cellobiose, maltose, lactose, sucrose, trehalose, melezitose, $\beta$-gentiobiose and maltotriose. Most strains produce acid from starch. Acid is not produced from erythritol, D- or L-arabinose, D- or L-xylose, adonitol, methyl $\beta$-xyloside, L-sorbose, rhamnose, dulcitol, inositol, sorbitol, methyl $\alpha$-D-mannoside, melibiose, inulin, D-raffinose, xylitol, D-lyxose, Dtagatose, D- or L-fucose, D- or L-arabitol, gluconate, 2ketogluconate or 5-ketogluconate. Most strains do not produce acid from glycogen and D-turanose. Mannitol acidification is variable. Positive in tests for acetoin, hippurate, aesculin, pyrrolidonyl arylamidase, leucine arylamidase and arginine dihydrolase; negative for $\beta$ glucuronidase, $\beta$-galactosidase, alkaline phosphatase and urease. Most strains are $\alpha$-galactosidase-negative. Positive enzymic hydrolysis of 4-methylumbelliferyl (4MU) $\beta$-D-glucoside, L-pyroglutamic acid 7-amido4-methyl coumarin (AMC), L-tryptophan, 4MU $N$-acetyl $\beta$-D-glucosaminide, $\quad p$-nitrophenyl $\beta$-Dcellobioside and $p$-nitrophenyl $\alpha$-D-maltoside; mostly positive for L-phenylalanine AMC, 4MU $\alpha$-D-glucoside, proline and leucine $p$-nitroanilide and $o$ - 
Table 3. Biochemical tests useful for the differentiation of E. haemoperoxidus sp. nov. and E. moraviensis sp. nov. from other enterococci

Taxa are identified as: 1, E. haemoperoxidus; 2, E. moraviensis; 3, E. faecalis; 4, the E. faecium group (E. faecium, E. durans, E. hirae, E. mundtii); 5, the E. avium group (E. avium, Enterococcus pseudoavium, E. malodoratus, Enterococcus raffinosus); 6, the E. gallinarum group (E. gallinarum, E. casseliflavus); 7, the Enterococcus cecorum group (E. cecorum, Enterococcus columbae); 8 , Enterococcus sulfureus; 9, Enterococcus saccharolyticus; 10, Enterococcus dispar; 11, Enterococcus asini. Data for E. asini were derived from de Vaux et al. (1998) and for the other species as well as species groups from Devriese \& Pot (1995) except the test results of D-tagatose for E. faecalis (Schleifer \& Kilpper-Bälz, 1984) and melibiose for E. sulfureus (Martinez-Murcia \& Collins, 1991). Characteristics are scored as: + , positive; $\mathrm{D}$, variable; $\mathrm{D}+$, usually positive; $\mathrm{D}-$, usually negative; - , negative.

\begin{tabular}{|c|c|c|c|c|c|c|c|c|c|c|c|}
\hline Characteristic & 1 & 2 & 3 & 4 & 5 & 6 & 7 & 8 & 9 & 10 & 11 \\
\hline \multicolumn{12}{|l|}{ Acidification of: } \\
\hline Sorbitol & - & - & $\mathrm{D}+$ & $\mathrm{D}-$ & + & $\mathrm{D}-$ & $\mathrm{D}$ & - & + & - & - \\
\hline Methyl $\alpha$-D-glucoside & + & + & - & - & $\mathrm{D}$ & + & $\mathrm{D}$ & + & + & + & - \\
\hline D-Tagatose & - & + & + & $\mathrm{D}$ & $\mathrm{D}+$ & $\mathrm{D}$ & $\mathrm{D}$ & - & - & + & - \\
\hline L-Arabinose & - & + & - & $\mathrm{D}$ & $\mathrm{D}$ & + & $\mathrm{D}$ & - & - & - & - \\
\hline Melibiose & - & - & - & $\mathrm{D}$ & $\mathrm{D}$ & + & + & + & + & $\mathrm{D}$ & - \\
\hline Melezitose & + & + & $\mathrm{D}+$ & - & $\mathrm{D}$ & $\mathrm{D}-$ & $\mathrm{D}$ & + & + & - & - \\
\hline Raffinose & - & $\mathrm{D}-$ & - & $\mathrm{D}$ & $\mathrm{D}$ & $\mathrm{D}$ & + & + & + & + & - \\
\hline Inulin & - & - & - & $\mathrm{D}-$ & - & $\mathrm{D}$ & + & - & + & - & - \\
\hline 2-Ketogluconate & - & - & $\mathrm{D}$ & - & + & - & $\mathrm{D}$ & + & + & + & - \\
\hline Arginine dihydrolase & + & - & + & + & - & + & - & - & - & + & - \\
\hline
\end{tabular}

nitrophenyl $\beta$-D-galactoside. Negative for hydrolysis of L-valine, $4 \mathrm{MU}$ phosphate, $4 \mathrm{MU} \beta$-D-glucuronide and L-isoleucine. Variable enzymic hydrolysis of $p$ nitrophenyl $\beta$-D-glucoside and $p$-nitrophenyl phosphate.

The type strain, $440^{\mathrm{T}}\left(=\mathrm{CCM} 4851^{\mathrm{T}}=\mathrm{LMG} 19487^{\mathrm{T}}\right)$, was isolated from service (non-potable) water and its characteristics agree with the species description above. Tests that are variable for E. haemoperoxidus strains give the following results for strain $440^{\mathrm{T}}$ : positive acidification of starch; negative for mannitol, glycogen and D-turanose. Weakly positive for $\alpha$ galactosidase. Positive for enzymic hydrolysis of $4 \mathrm{MU}$ $\alpha$-D-glucoside, L-phenylalanine AMC, proline and leucine $p$-nitroanilide, $o$-nitrophenyl $\beta$-D-galactoside, $p$-nitrophenyl $\beta$-D-glucoside and $p$-nitrophenyl phosphate. The strain is not pigmented. The $\mathrm{G}+\mathrm{C}$ content of strain $440^{\mathrm{T}}$ is $35 \cdot 3 \mathrm{~mol} \%$.

\section{Description of Enterococcus moraviensis sp. nov.}

Enterococcus moraviensis (mo.ra.vi.en'sis. N. L. adj. moraviensis pertaining to Moravia, the region in the Czech Republic from which the strains originate).

Gram-positive, ovoid cells occurring in pairs, short chains or in small groups, elongated in the direction of chains. Non-pigmented, non-motile, catalase-negative and group D antigen-positive. Weak amylase production on Columbia agar. Other physiological features as well as growth characteristics are as described above. Acid is produced from glycerol, Larabinose, ribose, galactose, D-glucose, D-fructose, D- mannose, mannitol, methyl $\alpha$-D-glucoside, $N$-acetylglucosamine, amygdalin, arbutin, salicin, cellobiose, maltose, lactose, sucrose, trehalose, melezitose, $\beta$ gentiobiose, D-turanose, D-tagatose and maltotriose. Most strains produce acid from inositol. Acid is not produced from erythritol, D-arabinose, D- or L-xylose, adonitol, methyl $\beta$-xyloside, rhamnose, dulcitol, sorbitol, methyl $\alpha$-D-mannoside, melibiose, inulin, xylitol, D-lyxose, D-or L-fucose, D- or L-arabitol, gluconate, 2ketogluconate or 5-ketogluconate. Most strains do not produce acid from L-sorbose, D-raffinose or glycogen. Acid production from starch is variable. Positive for acetoin, hippurate, aesculin and leucine arylamidase; mostly positive for $\beta$-galactosidase. Negative for $\beta$-glucuronidase, alkaline phosphatase, arginine dihydrolase and urease; mostly negative for $\alpha$ galactosidase. Variable for pyrrolidonyl arylamidase. Positive for enzymic hydrolysis of 4MU $\beta$-D-glucoside, $4 \mathrm{MU} \alpha$-D-glucoside, L-tryptophan, $4 \mathrm{MU} N$-acetyl $\beta$-Dglucosaminide, $p$-nitrophenyl $\beta$-D-cellobioside and $p$-nitrophenyl $\alpha$-D-maltoside; mostly positive for hydrolysis of L-pyroglutamic acid AMC and $o$ nitrophenyl $\beta$-D-galactoside. Negative for enzymic hydrolysis of $\mathrm{L}$-valine, $4 \mathrm{MU}$ phosphate, $4 \mathrm{MU} \beta$-Dglucuronide and L-isoleucine. Variable for hydrolysis of L-phenylalanine AMC, $p$-nitrophenyl $\beta$-D-glucoside, proline and leucine $p$-nitroanilide and $p$-nitrophenyl phosphate.

The type strain, $330^{\mathrm{T}}\left(=\mathrm{CCM} 4856^{\mathrm{T}}=\mathrm{LMG}\right.$ $19486^{\mathrm{T}}$ ), was isolated from spring water. It is positive in tests for inositol, starch, L-pyroglutamic acid AMC, $o$-nitrophenyl $\beta$-D-galactoside, proline and leucine $p$ nitroanilide and $\beta$-galactosidase; negative for L-sor- 
bose, D-raffinose, glycogen, pyrrolidonyl arylamidase, L-phenylalanine AMC, $p$-nitrophenyl $\beta$-D-glucoside, $p$-nitrophenyl phosphate and $\alpha$-galactosidase. All other characteristics are in agreement with the species description. The $\mathrm{G}+\mathrm{C}$ content of strain $330^{\mathrm{T}}$ is $36 \cdot 3$ $\mathrm{mol} \%$.

\section{ACKNOWLEDGEMENTS}

Special thanks to Arlette Vandekerckhove and Cindy Snauwaert for their excellent technical assistance. We thank Boleslav Otipka for providing bacterial cultures. P. S. was supported by a FEMS Fellowship 2000, obtained from the Federation of European Microbiological Societies. This work was supported in part by the European Communities project 'Enterococci in food fermentations. Functional and safety aspects' (FAIR programme FAIR-CT97-3078).

\section{REFERENCES}

Baele, M., Baele, P., Vaneechoutte, M., Storms, V., Butaye, P., Devriese, L. A., Verschraegen, G., Gillis, M. \& Haesebrouck, F. (2000). Application of tRNA intergenic spacer PCR for identification of Enterococcus species. J Clin Microbiol 38, 4201-4207.

Coenye, T., Falsen, E., Vancanneyt, M., Hoste, B., Govan, J. R. W., Kersters, K. \& Vandamme, P. (1999). Classification of Alcaligenes faecalis-like isolates from the environment and human clinical samples as Ralstonia gilardii sp. nov. Int J Syst Bacteriol 49, 405-413.

De Gheldre, Y., Vandamme, P., Goossens, H. \& Struelens, M. J. (1999). Identification of clinically relevant viridans streptococci by analysis of transfer DNA intergenic spacer length polymorphism. Int J Syst Bacteriol 49, 1591-1598.

Deibel, R. H. (1964). The group D streptococci. Bacteriol Rev 28 , 330-366.

Deibel, R. H. \& Evans, J. B. (1960). Modified benzidine test for the detection of cytochrome-containing respiratory systems in microorganisms. J Bacteriol 79, 356-360.

De Ley, J. (1970). Reexamination of the association between melting point, buoyant density, and chemical base composition of deoxyribonucleic acid. J Bacteriol 101, 738-754.

Devriese, L. A. \& Pot, B. (1995). The genus Enterococcus. In The Genera of Lactic Acid Bacteria, pp. 327-367. Edited by B. J. B. Wood \& W. H. Holzapfel. London: Blackie Academic \& Professional.

Devriese, L. A., Collins, M. D. \& Wirth, R. (1992). The genus Enterococcus. In The Prokaryotes: a Handbook on the Biology of Bacteria-Ecophysiology, Isolation, Identification, Applications, 2nd edn, vol. 2, pp. 1465-1481. Edited by A. Balows, H. G. Trüper, M. Dworkin, W. Harder \& K. H. Schleifer. New York: Springer.

Ehrenstein, B., Bernards, A. T., Dijkshoorn, L., Gerner-Smidt, P., Towner, K. J., Bouvet, P. J. M., Daschner, F. D. \& Grundmann, H. (1996). Acinetobacter species identification by using tRNA spacer fingerprinting. J Clin Microbiol 34, 2414-2420.

Ezaki, T., Hashimoto, Y. \& Yabuuchi, E. (1989). Fluorometric deoxyribonucleic acid-deoxyribonucleic acid hybridization in microdilution wells as an alternative to membrane filter hybridization in which radioisotopes are used to determine genetic relatedness among bacterial strains. Int J Syst Bacteriol 39, 224-229.

Facklam, R. R. \& Wilkinson, H. W. (1981). The family Strepto- coccaceae (medical aspects). In The Prokaryotes: a Handbook on Habitats, Isolation, and Identification of Bacteria, vol. 2, pp. 1572-1597. Edited by M. P. Starr, H. Stolp, H. G. Trüper, A. Balows \& H. G. Shlegel. New York: Springer.

Facklam, R. R., Sahm, D. F. \& Teixeira, L. M. (1999). Enterococcus. In Manual of Clinical Microbiology, 7th edn, pp. 297-305. Edited by P. R. Murray, E. J. Baron, M. A. Pfaller, F. C. Tenover \& R. H. Yolken. Washington, DC: American Society for Microbiology.

Felsenstein, J. (1989). PHYLIP - Phylogeny inference package (version 3.2). Cladistics 5, 164-166.

Gibson, C. M., Mallett, T. C., Claiborne, A. \& Caparon, M. G. (2000). Contribution of NADH oxidase to aerobic metabolism of Streptococcus pyogenes. J Bacteriol 182, 448-455.

Godfree, A. F., Kay, D. \& Wyer, M. D. (1997). Faecal streptococci as indicators of faecal contamination in water. J Appl Microbiol Symp Suppl 83, 110S-119S.

Jett, B. D., Huycke, M. M. \& Gilmore, M. S. (1994). Virulence of enterococci. Clin Microbiol Rev 7, 462-478.

McClelland, M., Petersen, C. \& Welsh, J. (1992). Length polymorphisms in tRNA intergenic spacers detected by using the polymerase chain reaction can distinguish streptococcal strains and species. J Clin Microbiol 30, 1499-1504.

McConaughy, B. L., Laird, C. D. \& McCarthy, B. J. (1969). Nucleic acid reassociation in formamide. Biochemistry 8, 3289-3295.

Maes, N., De Gheldre, Y., De Ryck, R., Vaneechoutte, M., Meugnier, H., Etienne, J. \& Struelens, M. J. (1997). Rapid and accurate identification of Staphylococcus species by tRNA intergenic spacer length polymorphism analysis. $J$ Clin Microbiol 35, 2477-2481.

Martinez-Murcia, A. J. \& Collins, M. D. (1991). Enterococcus sulfureus, a new yellow-pigmented Enterococcus species. FEMS Microbiol Lett 80, 69-74.

Mesbah, M., Premachandran, U. \& Whitman, W. B. (1989). Precise measurement of the $\mathrm{G}+\mathrm{C}$ content of deoxyribonucleic acid by high-performance liquid chromatography. Int $J$ Syst Bacteriol 39, 159-167.

Miller, H., Poole, L. B. \& Claiborne, A. (1990). Heterogeneity among the flavin-containing NADH peroxidases of group D streptococci. Analysis of the enzyme from Streptococcus faecalis ATCC 9790. J Biol Chem 265, 9857-9863.

Murray, B. E. (1990). The life and times of the enterococcus. Clin Microbiol Rev 3, 46-65.

Niemi, R. M., Niemelä, S. I., Bamford, D. H., Hantula, J., Hyvärinen, T., Forsten, T. \& Raateland, A. (1993). Presumptive fecal streptococci in environmental samples characterized by one-dimensional sodium dodecyl sulfate-polyacrylamide gel electrophoresis. Appl Environ Microbiol 59, 2190-2196.

Page, R. D. M. (1996). TREEVIEW: an application to display phylogenetic trees on personal computers. Comput Appl Biosci 12, 357-358.

Rurangirwa, F. R., Teitzel, C. A., Cui, J., French, D. M., McDonough, P. L. \& Besser, T. (2000). Streptococcus didelphis $\mathrm{sp.}$ nov., a streptococcus with marked catalase activity isolated from opossums (Didelphis virginiana) with suppurative dermatitis and liver fibrosis. Int J Syst Evol Microbiol 50, 759-765.

Schleifer, K. H. \& Kilpper-Bälz, R. (1984). Transfer of Streptococcus faecalis and Streptococcus faecium to the genus Enterococcus nom. rev. as Enterococcus faecalis comb. nov. and Enterococcus faecium comb. nov. Int J Syst Bacteriol 34, 31-34.

Seeley, H. W. \& VanDemark, P. J. (1951). An adaptive peroxidation by Streptococcus faecalis. J Bacteriol 61, 27-35. 
Smith, L. (1954). Bacterial cytochromes. Bacteriol Rev 18, 106-130.

Švec, P. \& Sedláček, I. (1999). Occurrence of Enterococcus spp. in waters. Folia Microbiol 44, 3-10.

Vancanneyt, M., Snauwaert, C., Cleenwerck, I. \& 8 other authors (2001). Enterococcus villorum sp. nov., an enteroadherent bacterium associated with diarrhoea in piglets. Int $J$ Syst Evol Microbiol 51, 393-400

Vaneechoutte, M., Boerlin, P., Tichy, H.-V., Bannerman, E., Jäger, B. \& Bille, J. (1998). Comparison of PCR-based DNA fingerprinting techniques for the identification of Listeria species and their use for atypical Listeria isolates. Int J Syst Bacteriol 48, 127-139. de Vaux, A., Laguerre, G., Diviès, C. \& Prévost, H. (1998). Enterococcus asini sp. nov. isolated from the caecum of donkeys (Equus asinus). Int J Syst Bacteriol 48, 383-387.

Welsh, J. \& McClelland, M. (1992). PCR-amplified length polymorphisms in tRNA intergenic spacers for categorizing staphylococci. Mol Microbiol 6, 1673-1680.

Whittenbury, R. (1978). Biochemical characteristics of Streptococcus species. In Streptococci, pp. 51-69. Edited by F. A. Skinner \& L. B. Quesnel. London: Academic Press.

Williams, A. M., Rodrigues, U. M. \& Collins, M. D. (1991). Intrageneric relationships of Enterococci as determined by reverse transcriptase sequencing of small-subunit rRNA. Res Microbiol 142, 67-74 